\title{
Studies on the Xanthine Oxidase Activity of Mammalian Cells
}

\author{
Horst Brunschede ${ }^{1}$ and Robert S. Krooth ${ }^{2}$
}

Received 6 March 1972-Final 8 Aug. 1972

Xanthine oxidase in man is confined to but a few tissues and is absent from cultured cell strains. In rodents, however, the enzyme is more widely distributed among the tissues and can be demonstrated in most cell lines. Rodents possess the enzyme uricase and are therefore able to carry purine catabolism one step further than man. Preliminary results suggest that uricase is restricted to but a few rodent tissues and is absent from cultured rodent cells. Hence it may be that in each species only the final enzyme of purine catabolism is tissue restricted. In other experiments, mammalian cells were grown in the presence of compounds known to induce xanthine oxidase in a eukaryotic fungus (Aspergillus nidulans). These compounds did not induce the enzyme in mammalian cells.

\section{INTRODUCTION}

In man and certain other primates, purine catabisolism does not go beyond uric acid (Keilin, 1959; Christen et al., 1970). Uricase, which converts uric acid to allantoin, is absent from these species, although it is present in all other mammalian species which have been studied. The enzyme which catalyzes the synthesis of uric acid (xanthine oxidase) is tissue restricted in man, being confined mainly to liver and gastrointestinal epithelium and absent (or present in negligible amounts) from most other tissues, including cultured human cells (Watts et al., 1965). Early studies (Morgan, 1926;

Supported by program project grants 1-PO-GM 15419 and GM 18153-01, National Institutes of Health, United States Public Health Service.

${ }^{1}$ Department of Human Genetics, University of Michigan Medical School, Ann Arbor, Michigan.

${ }^{2}$ Department of Human Genetics and Development, College of Physicians and Surgeons of Columbia University, New York, New York. 
Westerfeld and Richert, 1949; Richert and Westerfeld, 1951) of xanthine oxidase activity suggested that it was more widely distributed among the tissues of lower mammals.

In the work to be described, we attempted to do four things. First, we sought to confirm the absence of xanthine oxidase activity in cultured human cells. Second, we inquired into the tissue distribution of xanthine oxidase in a nonprimate mammal and looked for the activity in a variety of lines of cultured rodent cells. The interest of these experiments is that if one can find a line of mammalian cells which contains xanthine oxidase, one may have a way of employing microbiological methods for the study of uric acid synthesis in mammals. In addition, we hoped to answer the question of whether the enzyme is more widely distributed among the tissues in those species where xanthine oxidase is not the final enzyme of purine catabolism. In other words, is it usually only the final enzyme of the catabolic sequence which is tissue restricted? Third, in connection with this latter question, we made preliminary observations on the distribution of uricase among the tissue of a rodent. Fourth, we tried to induce xanthine oxidase in lines of human, and other mammalian, cells using compounds known to induce the enzyme in a eukaryotic fungus. These experiments of course deal with the question of whether the known inducers of the enzyme in one eukaryotic cell are effective in another one.

Studies which are helpful in obtaining an answer to the last question have been published by Scazzochio and Darlington (1968). These authors found that xanthine oxidase is inducible in Aspergillus nidulans. In this organism, the cellular level of activity is greatly increased if hypoxanthine or uric acid is present in the medium. The effect of hypoxanthine, but not of uric acid, is blocked if the medium contains allopurinol-a competitive inhibitor of xanthine oxidase. On the basis of these and other observations, Scazzochio and Darlington (1968) concluded that uric acid was a more proximate inducer of xanthine oxidase than hypoxanthine. The induction of an enzyme by its own product can, in theory, result in a circumstance where a transient chemical stimulus of the cell causes a hereditary change in cellular phenotype (without a change in the DNA). Product induction is represented in one of the "circuits" proposed by Monod and Jacob (1961) as a possible molecular model for cell differentiation in higher organisms.

\section{MATERIALS}

Xanthine oxidase (from milk, 0.14 unit/mg protein), uricase (from hog liver, approximately 14 units/g protein), and other biochemicals were obtained from Sigma Chemical Company, St. Louis, Missouri. Predicted optical extinction coefficients for hypoxanthine ( $249 \mathrm{~nm}, p H 7.0)$ and uric acid $(292 \mathrm{~nm}$, 
$p \mathrm{H} 7.0)$ were, respectively, 10.6 and 11.6 units of optical density per millimole per liter per centimeter of optical path. Weighed quantities of each compound exhibited $98-102 \%$ of the expected optical density. Uric acid-6- $\mathrm{C}^{14}$ was purchased from ICN Chemical and Isotope Division, Irvine, California. The purity of this preparation will be discussed in Results.

\section{Cell Strains}

Human fibroblasts were established from minced skin biopsies of a normal individual, strain CR, and of a patient, NAY, affected with the Lesch-Nyhan syndrome (Lesch and Nyhan, 1964). Strains EL and WI-38 (Hayflick and Moorhead, 1961) were developed from human embryonic lung tissue. S3 is a subline (Puck et al., 1956) of the HeLa cell (Gey et al., 1952). Strain $\mathrm{CHA}_{2}$ was derived from the V-79 Chinese hamster strain isolated by Ford and Yerganian (1958). Two clonal sublines of this strain have been designated M-IA and U-4. Strain CHO (Kao and Puck, 1967) is also a Chinese hamster line. The RAM (Krooth et al., 1964) and HR lines were developed from rat muscle tissue. Strain $\mathrm{MH}_{1} \mathrm{C}_{1}$ (kindly provided by Dr. A. H. Tashjian of the Harvard School of Dental Medicine) was obtained from a rat hepatoma and performs many liver-specific functions (Richardson et al., 1969; Tashiian et al., 1970). 3T3 is an established mouse line (Todaro and Green, 1963).

\section{Media}

Cells were grown in a medium previously described (Krooth, 1964) except that $12 \%$ fetal calf sera, rather than $12 \%$ human sera, were used in the present experiments. "Automedium" (Krooth, 1964) is a somewhat simpler medium and contains dialyzed rather than whole fetal calf sera. Both media are based on Eagle's (1959) Minimum Essential Medium.

\section{Animals}

Adult, white, male Sprague-Dawley rats were used.

\section{METHODS}

\section{Cell Culture Methods}

The methods employed for cell culture are given elsewhere (Krooth and Weinberg, 1961).

\section{Preparation of Cells for Assay}

Cells were washed twice with saline G (Puck et al., 1958) and harvested by incubation at $37 \mathrm{C}$ with $0.25 \%$ trypsin in tris-buffered saline (Martin, 1964). 
The cells were then sedimented by centrifugation and resuspended in a small volume of ice-cold $0.1 \mathrm{M}$ phosphate buffer, $p \mathrm{H}$ 7.8. Next the cells were disrupted by sonic energy (two pulses each of $30 \mathrm{sec}$ duration), using a Milard probe sonicator. Clear samples were obtained after centrifugation at $15,000 \times g$ for $10 \mathrm{~min}$, and were precipitated in an ice bucket for 30 min with 3 vol of a saturated $\left(\mathrm{NH}_{4}\right)_{2} \mathrm{SO}_{4}$ solution, $p \mathrm{H}$ 7.8. The precipitate was collected by centrifugation ( $30 \mathrm{~min}$ at $15,000 \times \mathrm{g}$ ) and dissolved in a small volume of $0.1 \mathrm{M}$ phosphate buffer, $p \mathrm{H}$ 7.8. This solution contained $70 \%$ of the xanthine oxidase activity initially present-a figure which was determined by the addition of purified enzyme to the cell suspension prior to sonication.

\section{Preparation of Rat Organ Homogenates}

Fresh tissue was excised and washed three times with saline to remove as much blood as possible. The specimen was then homogenized in a Waring blender (four cycles, each of $30 \mathrm{sec}$ duration) in $0.01 \mathrm{M}$ sodium phosphate buffer, $p \mathrm{H} \mathrm{7.0.} \mathrm{The} \mathrm{homogenate} \mathrm{was} \mathrm{further} \mathrm{dispersed} \mathrm{by} \mathrm{sonication} \mathrm{(four}$ pulses of $30 \mathrm{sec}$ duration) at $4 \mathrm{C}$. Clumps were removed by centrifugation, and the supernatant was frozen and stored at $-85 \mathrm{C}$. To determine the xanthine oxidase activity, the supernatant was thawed and the enzyme precipitated with $\left(\mathrm{NH}_{4}\right)_{2} \mathrm{SO}_{4}$, as described in the preceding paragraph.

\section{Determination of Xanthine Oxidase Activity}

Xanthine oxidase activity was measured colorimetrically by tetrazolium salt reduction as described by Fried (1966). The reaction mixture contained $1 \mathrm{mg}$ nitro blue tetrazolium (Sigma, grade III), $0.01 \mathrm{mg}$ phenazine methosulfate (Calbiochem), $0.1 \mu$ mole EDTA, and $0.2 \mathrm{mg}$ Bacto-gelatine (Difco) in a total volume of $1.4 \mathrm{ml}$ of $0.1 \mathrm{M}$ sodium phosphate buffer, $p \mathrm{H} \mathrm{7.8.} \mathrm{One} \mathrm{milliliter} \mathrm{of}$ cell protein solution was added to both sample and reference cuvettes $(1 \mathrm{~cm}$ lightpath), and the optical density at $540 \mathrm{~nm}$ was continuously monitored in a Beckman DB spectrophotometer. After determining that the recorded optical density gave a straight baseline, $0.6 \mu$ mole of hypoxanthine in $0.3 \mathrm{ml}$ sodium phosphate buffer $(p \mathrm{H} \mathrm{7.8)}$ was added to the sample (and $0.3 \mathrm{ml}$ of phosphate buffer was added to the reference cell). The rate of tetrazolium reduction was found to be linear between 2 and (at least) $10 \mathrm{~min}$ after the addition of substrate. During the first $2 \mathrm{~min}$ the rate was slightly higher than subsequently.

Under these conditions, the rate of tetrazolium reduction is proportional to cell protein concentration for concentrations of up to $13 \mathrm{mg}$ protein per milliliter of cell protein solution. On reducing weighed amounts of nitro blue tetrazolium nonenzymatically with $\mathrm{NADH}$, it was found that (under conditions of the assay) $1.0 \mathrm{OD}$ unit at $540 \mathrm{~nm}$ corresponds to the formation of 
$115 \mu \mathrm{g}$ formazan per milliliter. Converting known amounts of hypoxanthine to uric acid, with the commercially obtained purified enzyme, it was calculated that $1.0 \mathrm{OD}$ unit at $540 \mathrm{~nm}$ corresponds to the conversion of approximately 80 m $\mu$ moles hypoxanthine per milliliter.

The specificity of each assay was verified by the addition to the reaction mixture of allopurinol [4-hydroxypyrazole $(3,4-d)$-pyrimidine], a known inhibitor of xanthine oxidase (Watts et al., 1965). At a final concentration of 2.5 $\times 10^{-4} \mathrm{M}$, allopurinol completely inhibited enzyme activity in all preparations. The addition of purified enzyme to reaction mixtures which did not otherwise show xanthine oxidase activity resulted in a marked increase in $\mathrm{OD}_{540}$. The increase was linear with time and with quantity of purified enzyme added. The catalytic activity of the solutions of cell and tissue protein was destroyed when the solutions were boiled for $10 \mathrm{~min}$ prior to the assay.

\section{Determination of Uricase Activity}

Uricase was measured by the ability of a cell or tissue extract to effect the release of $\mathrm{C}^{14} \mathrm{O}_{2}$ from uric acid-6-C $\mathrm{C}^{14}$. The extract was incubated for $30 \mathrm{~min}$

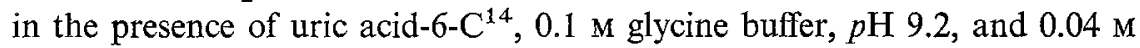
$\mathrm{Na}_{2} \mathrm{CO}_{3}$. The final volume was $1.8 \mathrm{ml}$. Only $64 \%$ of the counts in the commercial preparation of uric acid were releasable by purified uricase. The number of counts in $\mathrm{CO}_{2}$, derived from uric acid, was computed indirectly. Each sonicate was incubated in the presence of uric acid-6-C ${ }^{14}$ and in the presence and absence of excess unlabeled uric acid. By the solution of simultaneous equations, the counts in $\mathrm{CO}_{2}$ derived from uric acid could then be estimated. The final concentration of uric acid was varied over a range from $6.97 \times 10^{-5} \mathrm{M}$ to $2.88 \times 10^{-3} \mathrm{M}$, and the specific radioactivity over a range from 0.077 to $3.188 \mu \mathrm{c} / \mu$ mole. $\mathrm{CO}_{2}$ was trapped by methods described previously (Howell et al., 1967) except that in the present experiments we employed the liquid scintillation system of Jeffay (1963).

\section{Protein Determinations}

Protein determinations were performed according to the method of Lowry et al. (1951).

\section{RESULTS}

\section{Xanthine Oxidase Activity in Cultured Mammalian Cells}

Table I lists the cell strains which were tested for xanthine oxidase activity. As can be seen, none of the human cell lines had detectable enzymatic activity, whereas most of the rodent cell strains showed the presence of xanthine oxidase. 
Table I. Xanthine Oxidase Activity in Cultured Mammalian Cells

\begin{tabular}{|c|c|c|c|}
\hline $\begin{array}{l}\text { Cell } \\
\text { strain }\end{array}$ & Species of origin & $\begin{array}{l}\text { Xanthine oxidase activity } \\
\text { (units of } \mathrm{OD}_{540} / \mathrm{min} / \mathrm{mg} \\
\text { cell protein) } \times 100\end{array}$ & $\begin{array}{l}\text { mg protein/ } \\
\text { ml enzyme solution }\end{array}$ \\
\hline CR & Human & 0 & 6.08 \\
\hline NAY & Human & 0 & 8.4 \\
\hline EL & Human & 0 & 8.0 \\
\hline S3 & Human & 0 & 14.3 \\
\hline $\mathrm{CHA}_{2}$ & Chinese hamster & $2.75(356)$ & 14.8 \\
\hline M-IA & Chinese hamster & $0.40(51.8)$ & 18.7 \\
\hline U-4 & Chinese hamster & $7.66(993)$ & 21.7 \\
\hline CHO & Chinese hamster & 0 & 11.5 \\
\hline RAM & Rat & $1.66(215)$ & 6.6 \\
\hline HR & Rat & $0.87(113)$ & 4.4 \\
\hline $\mathrm{MH}_{1} \mathrm{C}_{1}$ & Rat & 0 & 6.8 \\
\hline $3 \mathrm{~T} 3$ & Mouse & $0.33(42.8)$ & 3.1 \\
\hline
\end{tabular}

${ }^{a}$ Numbers in parentheses denote millimicromoles product formed per hour of incubation per milligram cell protein. The zero entries for specific xanthine oxidase activity of course denote the absence of detectable catalytic activity. The assay employed will reliably detect a change in optical density of $0.05 \mathrm{OD}_{540}$ unit per minute.

\section{Xanthine Oxidase Activity of Rat Organs}

Table II shows that all rat organs tested, except brain, indeed do contain xanthine oxidase activity. Thus it appears that xanthine oxidase does not have the sharp tissue restriction in rodents that it has in man (Watts et al., 1965).

\section{Inducibility of Xanthine Oxidase in Cultured Cells}

Human diploid cells (strain CR) were grown for 6 days in automedium supplemented with one or all of the following ingredients: uric acid $(2.5 \times$ $\left.10^{-3} \mathrm{M}\right)$, allantoin $\left(5 \times 10^{-3} \mathrm{M}\right)$, and allantoic acid $\left(5 \times 10^{-3} \mathrm{M}\right)$. No xanthine oxidase activity was found in the cells. In addition, the enzyme could not be detected after growing CR cells in medium containing inosine $\left(1 \times 10^{-4} \mathrm{M}\right)$, hypoxanthine $\left(5 \times 10^{-4} \mathrm{M}\right)$, or xanthine $\left(2.5 \times 10^{-3} \mathrm{M}\right)$. An attempt was made to induce xanthine oxidase in human embryonic cells (EL cells). Embryonic lung tissue was minced and then cultured in automedium supplemented with $1 \times 10^{-3} \mathrm{M}$ uric acid. After 4 weeks of culture, no xanthine oxidase activity was detected in the cells.

We have also inquired whether the enzyme might be inducible in cells which spontaneously contain significant levels of activity. Accordingly, $\mathrm{CHA}_{2}$ cells were chosen for these experiments because of their high xanthine 
Table II. Xanthine Oxidase Activity of Whole Rat Organs

\begin{tabular}{lcc}
\hline Organ & $\begin{array}{c}\text { Xanthine oxidase activity } \\
\text { (units of } \text { OD }_{540} / \text { min/mg protein) }^{\prime}\end{array}$ & $\begin{array}{c}\text { mg protein/ } \\
\text { ml enzyme solution }\end{array}$ \\
\hline Liver & $2.12(275)$ & 9.25 \\
Heart & $0.096(12.4)$ & 4.40 \\
Muscle & $0.157(20.3)$ & 5.40 \\
Spleen & $0.84(109)$ & 7.03 \\
Kidney & $0.55(71.3)$ & 6.67 \\
Brain & 0 & 2.30 \\
& & \\
\hline${ }^{a}$ Numbers in parentheses denote millimicromoles product formed per hour of \\
incubation per milligram cell protein. The zero entry for specific xanthine \\
oxidase activity of course denotes the absence of detectable catalytic \\
activity. The assay employed will reliably detect a change in optical density \\
of 0.05 OD ${ }_{540}$ unit per minute. \\
${ }^{b}$ The homogenate prepared from rat heart may contain an inhibitor. Addi- \\
tion of heart homogenate to purified xanthine oxidase results in a $30^{\circ} \%$ \\
inhibition of the enzymatic activity.
\end{tabular}

Table III. Inducibility of Xanthine Oxidase in Chinese Hamster Cells

\begin{tabular}{lcc}
\hline \multicolumn{1}{c}{ Supplement } & $\begin{array}{c}\text { Xanthine oxidase activity }^{a} \\
\text { (units of } \text { OD }_{540} / \mathrm{min} / \mathrm{mg} \text { protein) }\end{array}$ & $\begin{array}{c}\text { mg protein/ } \\
\mathrm{ml} \text { enzyme solution }\end{array}$ \\
\hline $\begin{array}{l}\text { None } \\
\begin{array}{l}\text { Uric acid } \\
\left(1 \times 10^{-3} \mathrm{M}\right)\end{array}\end{array}$ & $2.75(356)$ & 14.80 \\
$\begin{array}{l}\text { Hypoxanthine } \\
\left(5 \times 10^{-4} \mathrm{M}\right)\end{array}$ & $2.77(359)$ & 9.45 \\
$\begin{array}{l}\text { Allopurinol } \\
\left(5 \times 10^{-5} \mathrm{M}\right)\end{array}$ & $1.50(194)$ & 9.90 \\
\hline
\end{tabular}

${ }^{a}$ Numbers in parentheses denote millimicromoles product formed per hour of incubation per milligram cell protein.

oxidase level (see Table I). However, as Table III shows, no evidence of induction of enzymatic activity by any of the compounds tested was found.

\section{Preliminary Observations on Uricase Activity in Rat Organs and in Cultured Mammalian Cells}

It was found that rat liver homogenate converts approximately $16 \mathrm{~m} \mu$ moles of uric acid/min/mg protein to allantoin. Rat spleen homogenate also exhibited uricase activity, although less than $\frac{1}{200}$ of the value found for liver. However, since the labeled uric acid used in these experiments could be shown to contain radiolabeled impurities ( $c f$. Methods), the reported values for uricase 
activity represent only an approximation, and the trace activity found in spleen is especially open to question. There was no uricase activity detectable in homogenates from rat heart, muscle, or brain. In addition, no uricase could be found in human diploid cells (WI-38), HeLa cells, S3 cells, 3T3 cells, and cultured cells derived from rat muscle (RAM), rat embryo, Chinese hamster $\left(\mathrm{CHA}_{2}\right.$ and NCTC 4206), Syrian hamster, Walker rat carcinoma, Schmidt-Ruppin carcinoma, and cottontail rabbit.

\section{DISCUSSION}

We have confirmed the earlier observation (Watts et al., 1965) that xanthine oxidase is absent from cultured human fibroblasts. Indeed this activity was undetectable in epithelialoid - as well as fibroblastic - human lines. However, the activity is readily detected in most rodent lines. As noted earlier, rodents have the enzyme uricase and can therefore carry purine catabolism one step further than man and a number of other primates. Yet uricase activity has not been found in lines of cultured rodent cells. Thus most lines of rodent cells are, in a sense, analogous to a whole human being, for the cells of these lines can presumably catabolize purines to uric acid, but no further. Such cells may therefore be useful in experiments aimed at generating models for purine catabolism in man.

The presence of xanthine oxidase activity in the rodent lines and its absence in human ones is of interest in other respects. Xanthine oxidase is presumably repressed in some way in the cultured human cells. Will rodenthuman somatic cell hybrids contain xanthine oxidase activity? Previous somatic cell crosses involving tissue-restricted functions have been obtained by hybridizing a cell line which performs such a function with a cell line that does not (Davidson, 1970). The function in every case has been thought to be tissue restricted in both parental species. No studies have been reported on functions which are normally tissue restricted in one parental species and are normally not tissue restricted in the other. Conceivably, through the application of the technique of somatic cell hybridization, it may eventually be possible to isolate clones of cells which synthesize human, as well as rodent, xanthine oxidase (Krooth and Sell, 1970; Klebe et al., 1970; Weiss and Chaplain, 1971). Such clones, if they could be obtained, might make it feasible to study the xanthine oxidase of patients with various forms of gout without having to biopsy internal organs. Lastly, one may ask whether the presence of xanthine oxidase in the cultured cells of a species that can carry uric acid catabolism one step further than man means that the enzyme is not tissue restricted in that species. Our results indicate that xanthine oxidase is not tissue restricted in rodents, and our preliminary results suggest that in the rat uricase (the final enzyme of the catabolic sequence in rodents) is confined 
to but one or two organs. Hence it may be that only the final enzyme of the catabolic sequence, in each species, is tissue restricted. We are aware, however, that to prove this generalization further experiments are necessary. We have not of course exhausted all the ways of trying to demonstrate xanthine oxidase in the tissues and cells from which it appears to be absent. Moreover, we have measured the enzyme by its catalytic activity rather than by, say, its antigenic activity or some other index which might be less sensitive to experimental conditions. In addition, the generalization predicts that in forms which can catabolize purines one step further than rodents (as a result of allantoinase activity), uricase will be widely distributed among the tissues, and allantoinase only narrowly. We have not tested that prediction. Finally, our assay for uricase is still imperfect, because of a contaminant which we are unable to eliminate in one of our reagents. Despite these reservations the experimental predictions thus far tested make one suspect that the generalization holds.

\section{REFERENCES}

Christen, P., Peacock, W. C., and Wacker, W. E. C. (1970). Urote oxidase in primate phylogenesis. Europ. J. Biochem. 12:3.

Davidson, R. L. (1970). Regulation of gene expression in somatic cell hybrids. In Vitro 6:411.

Eagle, H. (1959). Amino acid metabolism in mammalian cell cultures. Science 130:432.

Ford, D. K., and Yerganian, G. (1958). Observations on the chromosomes of Chinese hamster cells in tissue culture. J. Natl. Cancer Inst. 21:393.

Fried, R. (1966). Colorimetric determination of xanthine dehydrogenase by tetrazolium reduction. Anal. Biochem. 16:427.

Gey, G. O., Coffman, W. D., and Kubicek, M. T. (1952). Tissue culture studies of the proliferative capacity of cervical carcinoma and normal epithelium. Cancer Res. 12:264.

Hayfick, L., and Moorhead, P. S. (1961). The serial cultivation of human diploid cell strains. Exptl. Cell Res. 25:585.

Howell, R. R., Klinenberg, J. R., and Krooth, R. S. (1967). Enzyme studies on diploid cell strains developed from patients with hereditary orotic aciduria. Johns Hopkins Med.J. $120: 81$.

Jeffay, H. (1963). Counting $\mathrm{C}^{14} \mathrm{O}_{2}$ with a liquid scintillation counter. In Rothschild, S. (ed.), Advances in Tracer Methodology, Vol. 1, Plenum Press, New York, p. 113.

Kao, F. T., and Puck, T. T. (1967). Genetics of somatic mammalian cells. IV. Properties of Chinese hamster cell mutants with respect to the requirement for proline. Genetics $55: 514$.

Keilin, J. (1959). The biological significance of uric acid and guanine excretion. Biol. Rev. Cambridge Phil. Soc. 34:265.

Klebe, R. J., Chen, T., and Ruddle, F. H. (1970). Mapping of a human genetic regulator element by somatic cell genetic analysis. Proc. Natl. Acad. Sci. 66:1220.

Krooth, R. S. (1964). Properties of diploid cell strains developed from patients with an inherited abnormality of uridine biosynthesis. Cold Spring Harbor Symp. Quant. Biol. 29:189

Krooth, R. S., and Sell, E. K. (1970). The action of Mendelian genes in human diploid cell strains. J. Cell. Physiol. 76:311.

Krooth, R. S., and Weinberg, A. N. (1961). Studies on cell lines developed from the tissues of patients with galactosemia. J. Exptl. Med. 113:1155. 
Krooth, R. S., Shaw, M. W., and Campbell, B. K. (1964). A persistent strain of diploid fibroblasts. J. Natl. Cancer Inst. $31: 1031$.

Lesch, M., and Nyhan, W. L. (1964). A familial disorder of uric acid metabolism and central nervous system function. Am. J. Med. 36:561.

Lowry, O. H., Rosebrough, N. J., Farr, A. L., and Randall, R. J. (1951). Protein measurement with the Folin phenol reagent. J. Biol. Chem. 193:265.

Martin, G. M. (1964). Use of tris (hydroxymethyl) aminomethane buffers in cultures of diploid human fibroblasts. Proc. Soc. Exptl. Biol. Med. 116:167.

Monod, J., and Jacob, F. (1961). General conclusions: Telonomic mechanisms in cellular metabolism, growth, and differentiation. Cold Spring Harbor Symp. Quant. Biol. 26:389.

Morgan, E. J. (1926). The distribution of xanthine oxidase. I. Biochem. J. 20:1282.

Puck, T. T., Marcus, P. I., and Cieciura, S. J. (1956). Clonal growth of mammalian cells in vitro. Growth characteristics of colonies from single HeLa cells with and without a "feeder" layer. J. Exptl. Med. 103:273.

Puck, T. T., Cieciura, S. J., and Robinson, A. (1958). Genetics of somatic mammalian cells. III. Long term cultivation of euploid cells from human and animal subjects. J. Exptl. Med. 108:945.

Richardson, U. I., Tashjian, A. H., and Levine, L. (1969). Establishment of a clonal strain of hepatoma cells which secrete albumin. J. Cell Biol. 40:236.

Richert, D. A., and Westerfeld, W. W. (1951). Xanthine oxidase in different species. Proc. Soc. Exptl. Biol. Med. 76:252.

Scazzochio, C., and Darlington, A. J. (1968). The induction and repression of the enzymes of purine breakdown in Aspergillus nidulans. Biochim. Biophys. Acta 166:557.

Tashjian, A. H., Bancroft, F. C., Richardson, U. I., Goldlust, M. B., Rommel, F. A., and Ofner, P. (1970). Multiple differentiated function in an unusual clonal strain of hepatoma cells. In Vitro 6:32.

Todaro, G. J., and Green, H. (1963). Quantitative studies of the growth of mouse embryo cells in culture and their development into established cell lines. J. Cell. Biol. 17:299.

Watts, R. W. E., Watts, J. E. M., and Seegmiller, J. E. (1965). Xanthine oxidase activity in human tissues and its inhibition by allopurinol. J. Lab. Clin. Med. 66:688.

Weiss, M. C., and Chaplain, M. (1971). Expression of differentiated functions in hepatoma cell hybrids: Reappearance of tyrosine aminotransferase inducibility after the loss of chromosomes. Proc. Natl. Acad. Sci. 68:3026.

Westerfeld, W. W., and Richert, D. A. (1949). The xanthine oxidase activity of rat tissues. Proc. Soc. Exptl. Biol. Med. 71:181. 